\begin{tabular}{c|l|l|l}
$\begin{array}{c}\text { Case Reports in } \\
\text { Oncology }\end{array}$ & $\begin{array}{l}\text { Case Rep Oncol 2010;3:410-415 } \\
\text { DOI: 10.1159/000321270 }\end{array}$ & $\begin{array}{l}\text { Published online: } \\
\text { November 13, 2010 }\end{array}$ & $\begin{array}{l}\text { O 2010 S. Karger AG, Basel } \\
\text { ISSN 1662-6575 } \\
\text { www.karger.com/cro }\end{array}$ \\
\hline
\end{tabular}

This is an Open Access article licensed under the terms of the Creative Commons AttributionNonCommercial-NoDerivs 3.0 License (www.karger.com/OA-license), applicable to the online version of the article only. Distribution for non-commercial purposes only.

\title{
Invasive Papillary Breast Carcinoma
}

\author{
S.J. Bhosale A.Y. Kshirsagar S.R. Sulhyan S.V. Jagtap \\ Y.P. Nikam \\ Krishna Institute of Medical Sciences University, Karad, India
}

\section{Key Words}

Breast cancer $\cdot$ Invasive papillary carcinoma $\cdot$ Infiltrating ductal carcinoma

\begin{abstract}
We present the case of a 55-year-old postmenopausal female who presented with complaints of a gradually increasing painless subareolar mass in the left breast of 4 months' duration. Left-sided modified radical mastectomy was performed and the specimen was histopathologically diagnosed as invasive papillary carcinoma. Immunohistochemistry confirmed this diagnosis. All 8 excised axillary lymph nodes were negative for malignant cells. Postoperative chemotherapy was given and for the past 6 months, the patient has maintained a regular follow-up on an outpatient basis. She does not have any evidence of either local or distant recurrence of tumour metastases.
\end{abstract}

\section{Introduction}

The overall incidence of invasive papillary carcinomas is rare, accounting for less than $1-2 \%$ of invasive breast cancers. They are most commonly seen in postmenopausal females and are rare in males [1]. Here, we present a case of invasive papillary carcinoma in a postmenopausal woman. We report this case because of its rarity.

\section{Case Presentation}

A 55-year-old postmenopausal female presented with a painless subareolar mass in the left breast of 4 months' duration, gradually increasing in size.

On examination, there was a single, $3 \times 3 \mathrm{~cm}$, firm, well-circumscribed, palpable lump in the subareolar region of the left breast. The nipple was retracted, without ulceration or discharge, and left axillary lymph nodes were not palpable. Opposite breast, axilla and systemic examinations were normal. Fine needle aspiration cytology of the mass was positive for malignant cells and a left-sided modified radical mastectomy was done. On gross examination (fig. 1 , fig. 2 ), the lesion was gray white and $3 \times 2$ $\times 2 \mathrm{~cm}$ in size. The nipple was partially retracted and the skin of the areola was wrinkled. The cut surface showed a well-circumscribed, solid, cystic, granular mass measuring $3 \times 2 \times 2 \mathrm{~cm}$ with areas of hemorrhage, occupying almost the whole breast and surrounded by fibrous tissue. Histopathological 


\begin{tabular}{c|l|l|l}
$\begin{array}{c}\text { Case Reports in } \\
\text { OICOOIJ }\end{array}$ & $\begin{array}{l}\text { Case Rep Oncol 2010;3:410-415 } \\
\text { DOl: 10.1159/000321270 }\end{array}$ & $\begin{array}{l}\text { Published online: } \\
\text { November 13, 2010 }\end{array}$ & $\begin{array}{l}\odot \text { ISSN 1662-6575 } \\
\text { www.karger.com/cro }\end{array}$ \\
\hline
\end{tabular}

findings (fig. 3 , fig. 4 , fig. 5 ) were consistent with the diagnosis of invasive papillary carcinoma, with all surgical margins free of tumour. All 8 excised axillary lymph nodes were negative for malignant cells and immunohistochemistry (IHC) confirmed the diagnosis.

Postoperatively, the patient underwent chemotherapy and recovered uneventfully.

\section{Discussion}

Invasive papillary carcinomas of the breast are rare, accounting for less than 1-2\% of invasive breast cancers. They occur most frequently in postmenopausal women in the 6th to 8 th decade of life and in non-white women. More than $75 \%$ of the cases include a ductal carcinoma in situ (DCIS) component [1-3].

The main difference between papillary cancer and other breast cancers is the appearance of the cells under a microscope. The cells are arranged in little papules or finger-like projections [2].

A confusing factor in the classification and histological analysis of DCIS is microinvasion. Patients having DCIS with microinvasion may present with axillary lymph node metastases, whereas DCIS patients without microinvasion usually do not present with axillary metastases. Both DCIS and invasive breast cancer have similar risk factors [4].

IHC is very useful in the assessment of invasion. The examination of myoepithelial cells and basement membrane is an important step for the diagnosis of invasive cancers. Myoepithelial cells are absent in invasive cancers, but some of them may produce basement membrane. There are a number of markers, known as myoepithelial markers, which identify myoepithelial cells. These are S-100, $\alpha$-smooth muscle actin, smooth muscle myosin heavy chain, calponin, maspin, CD10, P63 and high-molecular weight cytokeratin, and all of them have different sensitivities and specificities. Of these myoepithelial markers, smooth muscle myosin heavy chain and P63 are specific; for example, P63 is a special myoepithelial marker which stains the cell nucleus only [4].

In spite of all these available myoepithelial markers, it is not practical to routinely perform IHC staining in all cases. One important microscopic feature detected by HE staining which differentiates invasive cancers from DCIS is the presence of a concentric stromal reaction around the invasive cancer, which is absent in DCIS. Another feature is the presence of an irregular circumference of the foci of invasive cancer cells in invasive cancers, which is not seen in DCIS [4].

The treatments for invasive ductal carcinoma fall into 2 broad categories: either local or systemic treatment. Local treatment consists of surgery and radiation therapy. Surgical options include lumpectomy and mastectomy (partial, total or modified), and radiation therapy is most often recommended after surgeries that conserve healthy breast tissue, such as lumpectomy and partial mastectomy [1]. Systemic treatments include chemotherapy, hormonal therapy and targeted therapies [1]. Papillary breast cancers are estrogen receptor and progesterone receptor positive [5]. 


\begin{tabular}{c|l|l|l}
$\begin{array}{c}\text { Case Reports in } \\
\text { Oncology }\end{array}$ & $\begin{array}{l}\text { Case Rep Oncol 2010;3:410-415 } \\
\text { DOI: 10.1159/000321270 }\end{array}$ & $\begin{array}{l}\text { Published online: } \\
\text { November 13, 2010 }\end{array}$ & $\begin{array}{l}\text { O 2010 S. Karger AG, Basel } \\
\text { ISSN 1662-6575 } \\
\text { www.karger.com/cro }\end{array}$ \\
\hline
\end{tabular}

\section{Conclusion}

In $75 \%$ of papillary carcinoma cases, the cancer spreads to the lymph nodes; however, overall, patients with papillary carcinomas have a better prognosis than patients with other, more common breast cancers [2].

The detection of DCIS has increased due to the availability of newer diagnostic modalities like mammography. However, to differentiate between DCISs and invasive cancers, IHC and the presence of certain morphologic features (detected by HE staining) are needed [3].

Most cases of papillary carcinoma are low-grade, slow-growing cancers, with good recovery. Many papillary carcinomas do not spread very far beyond their original site [4].

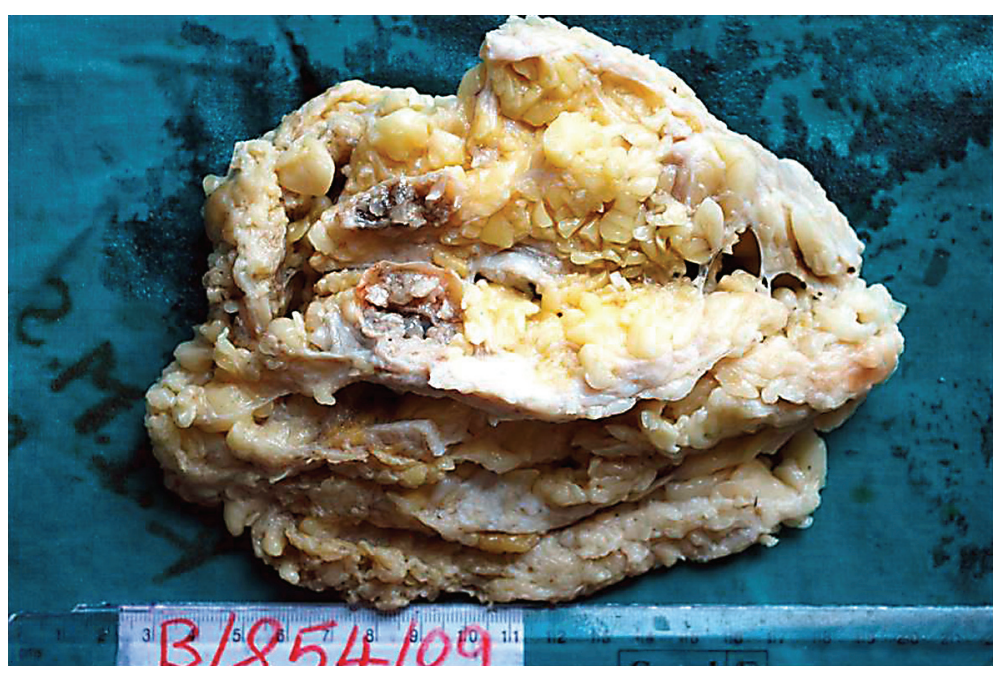

Fig. 1. Modified radical mastectomy gross specimen showing the cystic and solid tumour mass. 


\begin{tabular}{c|l|l|l}
$\begin{array}{c}\text { Case Reports in } \\
\text { Oncology }\end{array}$ & $\begin{array}{l}\text { Case Rep Oncol 2010;3:410-415 } \\
\text { DOI: 10.1159/000321270 }\end{array}$ & $\begin{array}{l}\text { Published online: } \\
\text { November 13, 2010 }\end{array}$ & $\begin{array}{l}\text { O 2010 S. Karger AG, Basel } \\
\text { ISSN 1662-6575 } \\
\text { www.karger.com/cro }\end{array}$ \\
\hline
\end{tabular}

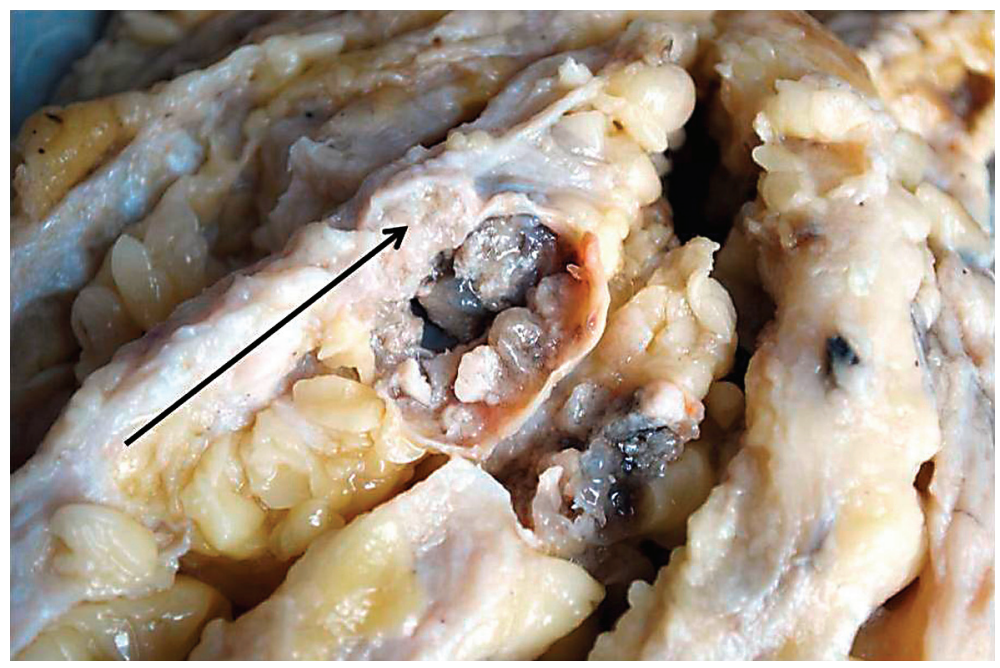

Fig. 2. Cystic papillary tumour with soild area of invasion.

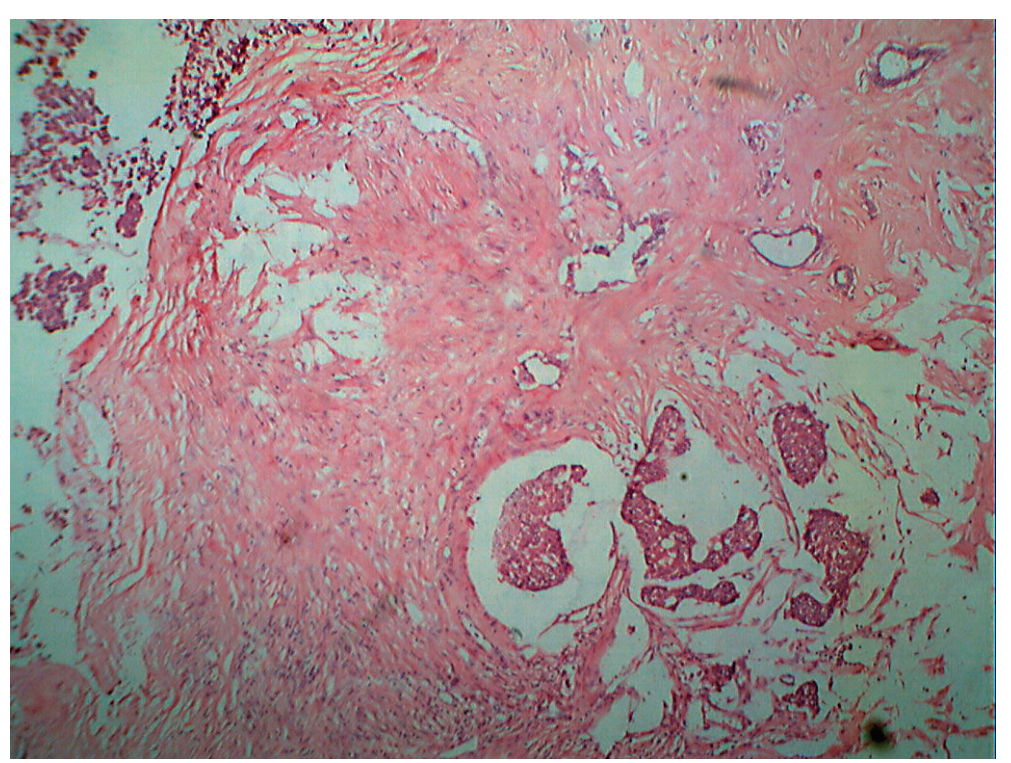

Fig. 3. Solid variant of papillary carcinoma invading the wall. HE staining; magnification $\times 10$. 


\begin{tabular}{c|l|l|l}
$\begin{array}{c}\text { Case Reports in } \\
\text { Oncology }\end{array}$ & $\begin{array}{l}\text { Case Rep Oncol 2010;3:410-415 } \\
\text { DOI: 10.1159/000321270 }\end{array}$ & $\begin{array}{l}\text { Published online: } \\
\text { November 13, 2010 }\end{array}$ & $\begin{array}{l}\odot \text { 2010 S. Karger AG, Basel } \\
\text { ISS 1662-6575 } \\
\text { www.karger.com/cro }\end{array}$ \\
\hline
\end{tabular}

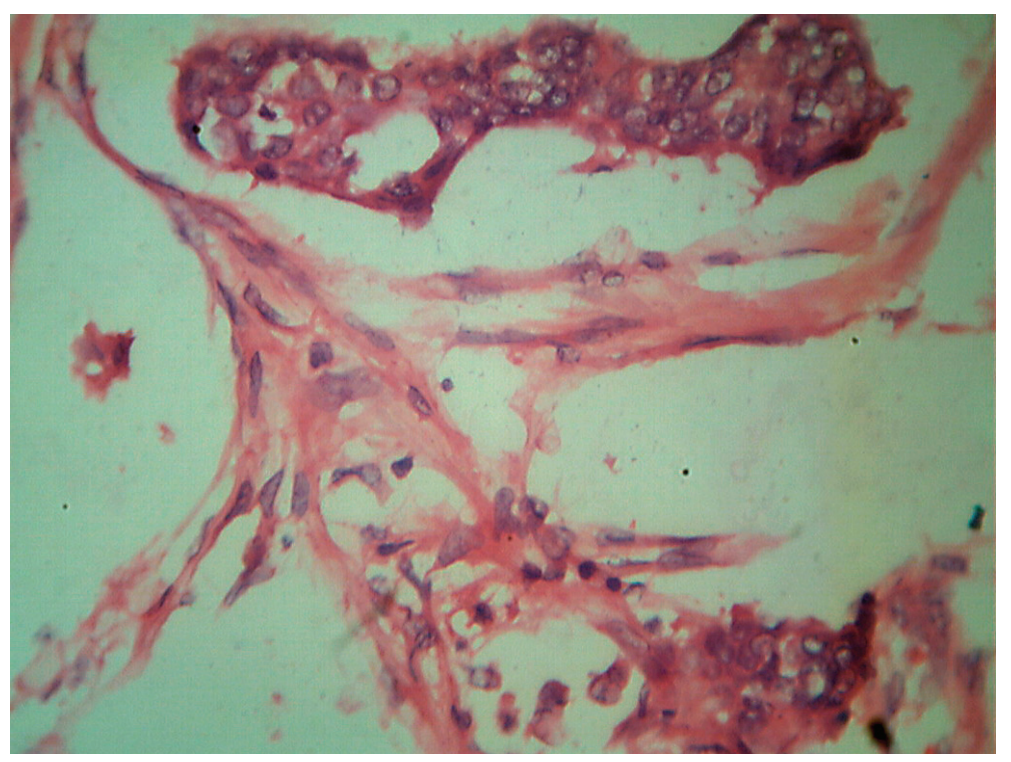

Fig. 4. Malignant papillary lesion. HE staining; magnification $\times 40$.

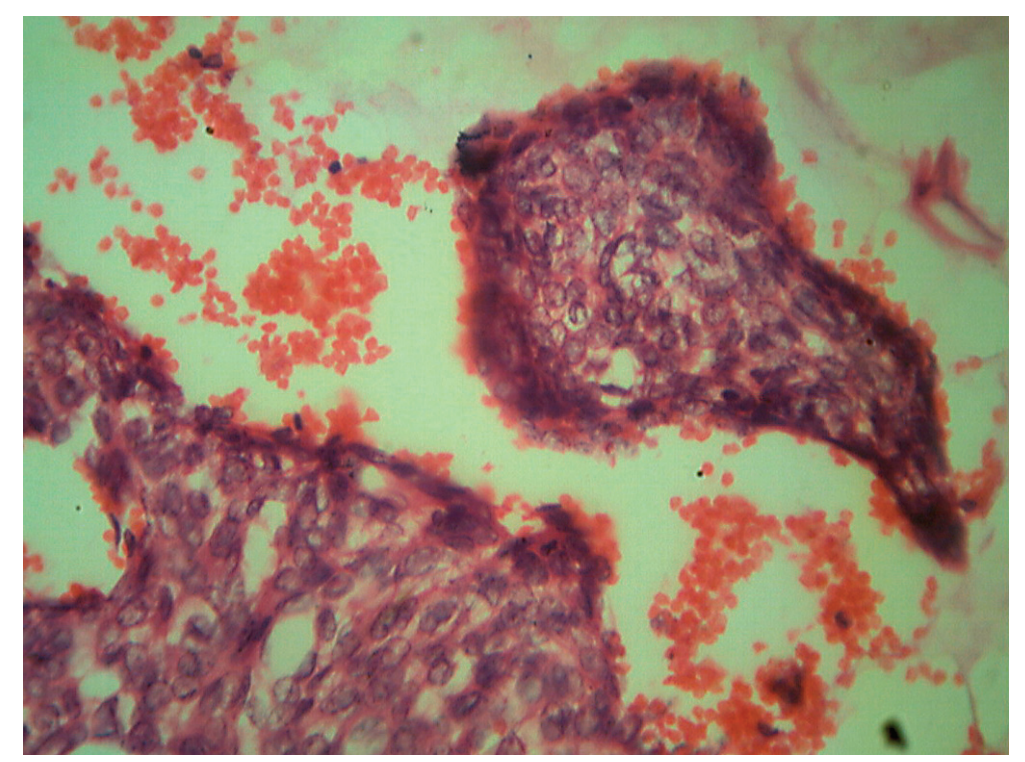

Fig. 5. Papillary carcinoma of the breast. HE staining; magnification $\times 40$. 


\section{References}

1 http://www.breastcancer.org/symptoms/types/rare_idc/papillary.jsp.

2 http://www.networkofstrength.org/information/diagnosis/rare/papillary.php.

3 Elverici E, Barça AN, Türksoy O, Araz L, Yüksel E: Bilateral invasive papillary carcinoma of the breast. Clin Imaging 2007;31:419-421.

4 Pervez S, Khan H: Infiltrating ductal carcinoma breast with central necrosis closely mimicking ductal carcinoma in situ (comedo type): a case series. J Med Case Reports 2007;1:83.

5 http://cancer.stanford.edu/breastcancer/invasive.html. 